\title{
SHARP RAYS: JAVANESE RESPONSES TO A SOLAR ECLIPSE
}

\author{
Ward Keeler*
}

When a total solar eclipse occurred over Central Java late in the morning of June 11, 1983, the air became very still and Java's lush vegetation glowed in the eerie light characteristic of sunset in the tropics. As at sunset, too, the horizon turned red, but it did so not only in the west but in all directions, and in the half-light distant volcanoes usually obscured by the glare of the sun became visible. For the four minutes of total eclipse, the sun, almost directly overhead, looked like a black ball surrounded by a brilliant white light. Most eerily of all, in one of the most densely populated rural areas in the world, there was no traffic on the roads, no movement in towns or villages, and no one watching the eclipse.

The Indonesian government had gone to great lengths to make sure that people would not damage their eyes by observing the eclipse directly. In Central Java, this campaign was so effective that virtually no one dared even to look outside, let alone look at the sky, for a period of about three hours before and after as well as during the eclipse. People stayed inside their houses, some watching the eclipse on television, others lying in bed, all thoroughly intimidated by what had come to be known as the sun's "sharp rays."

Javanese reactions to the eclipse raise two questions: 1) why was the populace so receptive to official efforts to prevent people from observing the eclipse; and 2) why were members of the government, from the top down, so enormously concerned about it? The remarks that follow are based on conversations I had with Javanese, most of them peasants, many of them friends living in a village in which I had lived for twenty months in 1978-1979, and to which I returned for the months of June, July, and August 1983. What the eclipse demonstrated was how widely shared understandings of the cosmos and officially promulgated understandings of the polity drew on a common set of assumptions about great events, their implicit meanings, and dangers abroad in the world.

\section{The Eclipse}

Newspapers, radio, and television carried stories about the eclipse for weeks prior to the event. Village offices and many crossroads displayed posters with the message that watching the eclipse would make one go blind. In Karanganom, the village where I was staying, the headman traveled slowly about each hamlet during the days preceding the eclipse, repeating this message over a loudspeaker attached to the roof of his white jeep.

\footnotetext{
* This article is based on the final report I submitted to the Indonesian Institute of Sciences at the end of my stay in Java, in September 1983. I am indebted to Mr. Napitupulu and other members of that institute for granting me the research permit that enabled me to do research in Indonesia. The project was supported by a grant from the from the National Science Foundation. I wrote the article while a member at the Institute for Advanced Study, Princeton, supported by the National Endowment for the Humanities. I also wish to thank Benedict Anderson, A. L. Becker, Judith Becker, George Bond, Dale Eickelman, Gillian Fecley-Harnik, and Leslie Morris, for comments on an earlier draft of this cssay.
} 
He announced that parents must be careful to gather together all their children, and the whole family stay inside the house from nine in the morning until two in the afternoon on the day of the eclipse. (Directives from the central government reportedly indicated that people were to stay inside from ten until one. But zealous village headmen extended those hours, some ordering people to stay inside from as early as eight in the morning and till as late as four in the afternoon.) People were also instructed to protect their livestock. Some people devised coverings for their pens and cages; others simply took them inside the house.

Javanese peasants' houses are roofed with tiles, a few glass or plastic tiles substituting for the usual clay ones in order to allow light into the generally windowless interiors. These transparent tiles were carefully covered over or replaced by clay tiles prior to the eclipse, making it necessary to light a kerosene lamp, even during the day, to see anything. Houses of recent construction have air vents above windows and doors. These were stuffed with cloth, or covered with opaque paper, lest any light enter. Some people laid in supplies of food, both because markets would be closed the day of the eclipse, and because there was a general feeling that one should be prepared for any and all events.

The government encouraged people to watch the eclipse on television, and on the morning of the eclipse, many people gathered in the houses of neighbors owning television sets. The Indonesian television coverage of the event suffered from the usual difficulties about live events: events in life happen much too slowly for TV. Pictures of the sun as it gradually went dark, to appropriately spacey music, alternated first with patently staged scenes of "peasants" responding to the event in superstitious ways, then with shots of downtown Jakarta. The programming was being relayed directly to Europe, and this presentation of "traditional" and "modern" views of Indonesia seemed packaged for foreign consumption.

At the village office in Karanganom, a village official watched television along with several other residents. At nine o'clock, and again at the time the eclipse actually began a little while later, he signaled the event by running the siren on the village jeep, amplified by a microphone and loudspeaker. He also announced at various times what proportion of the sun was covered, stressing the increasing danger of the moment. When any of the children watching television turned to look outside, he ordered them to face the television again.

The shadow puppeteer with whose family I was staying, Pak Cermadikrama, had performed a play the night before the eclipse. Performances of shadow plays usually start at nine in the evening and last till five the following morning. Because no one wanted to be traveling about on the morning of the eclipse, however, the puppeteer and the performance's sponsors agreed to have it begin at seven-thirty and end at three-thirty a.m. That way the stage could be disassembled and the participants all get home well before the eclipse began. Pak Cerma went to bed once he got home, and both he and one of his sons woke up after the eclipse had already begun. Both wanted to watch the eclipse on the neighbors' television but were fearful of walking the fifteen yards or so to the neighbors' house. The eighteen-year-old son tied a handkerchief over his eyes and felt his way to the neighbors' door. His father threw his sarung over his head and ran.

Many people, especially older ones, chose to spend the morning in bed. Several old men told me that they did so even though there was a television on in their homes, with many relatives and neighbors watching it. Sleeping late in the morning is not a Javanese form of luxury. It is, instead, a rather common response to fear, and these peo- 
ple felt no compunction about saying that they had lain in bed because they felt afraid. One man in Karanganom reported that he, his wife, and daughter, had all stayed in bed during the eclipse. He had needed to urinate but, too scared to go outside, he had had no choice but to pee in a corner.

About twenty minutes after the eclipse occurred over Central Java, it occurred over South Sulawesi, and television coverage accordingly shifted from scenes in Java to the city of Ujung Pandang. After the extraordinary stillness of Central Java during the whole morning of the eclipse, the street scenes of Ujung Pandang were astonishing: traffic was still dense, though drivers had turned on their headlights, and pedestrians walked the streets as though it were any other day. I don't know whether the regional government was less energetic in its campaign to protect people's sight in Sulawesi. From the perspective of Central Java, I was inclined to attribute the populace's nonchalance to the intemperate boldness for which Makasarese and Buginese are famed. In any case, the contrast with Central Java, where at that moment people were still discouraged from and fearful of going outside, was telling proof that the government's policy and Javanese inclinations found a peculiarly close fit.

As soon as the eclipse was over, many people expressed some surprise at how inconsequential it had seemed. Nevertheless, belief in the special, dangerous nature of the sun's rays during the eclipse remained strong. Stories of hundreds of people going blind in Yogya and Semarang, and of two or three people losing their sight in villages near Karanganom, went round for several days after the event. Eventually, these numbers were reduced. Educated villagers who read the newspaper reported that hundreds of people had indeed gone to the eye clinic in Yogya, but that this was out of the fear that they had been "struck by rays" (kena sinar). They turned out to have either no symptoms or conjunctivitis. But it was still believed that some people had truly gone blind from looking directly at the sun during the eclipse.

Actually, many Javanese laughed, after the fact, at how overwrought they had become. A few highly educated Javanese were bitter that they had missed out on their one chance to witness a total solar eclipse. But the fear in the air was very hard to resist: Westerners staying in Java were by no means impervious to it. It is the roots of this fear that need to be explained.

\section{Interpreting the Eclipse}

Mention of an eclipse in far-away places is liable to evoke images of natives gazing fearfully at the heavens, a Tylorean proto-scientist or two among them trying, with knitted brow, to conceive of what might explain the sudden darkness. What this conventional image disregards is the inevitable presence of clever and/or privileged people whose brows knit, not in the service of science, but out of a concern for what worldly meanings their fellows will read into the event.

Meanings of any sort must be gathered through the work of interpretation, and interpretation must always be negotiated. Interpretation, like thinking ${ }^{1}$ and feeling, ${ }^{2}$ is a public activity, an ongoing and essential part of everybody's social life. It follows that

\footnotetext{
${ }^{1}$ See Clifford Geertz, "Person, Time and Conduct in Bali," in Geertz, The Interpretation of Cultures (New York: Basic Books, 1973), pp. 360-411.

2 See Michelle Z. Rosaldo, Knowledge and Passion: llongot Notions of Self and Social Life (Cambridge: Cambridge University Press, 1980).
} 
everything, no matter how "ordinary," is meaningful, and that no meaning, however "obvious," is given. Yet, from time to time, the extraordinary irrupts into people's daily lives, however humdrum, and on such occasions an outsider can see the interpretive process undertaken on a grand scale. When the cosmos puts itself on show, vast numbers of people join simultaneously in the effort to construe the event and render the extraordinary sensible. Precisely because such interpretation is even more public than usual, the results are unlikely to be either neutral or uniform. Instead, the construction of a cosmological event is subject to interested manipulation on the part of many.

In speaking to Javanese about the eclipse, I was impressed by the way that ideas that I would label psychological, cosmological, and political informed both their actions and their comments. But to make such distinctions is misleading. It was precisely the range of meanings with which the eclipse was endowed, and their conflation, that made it such an impressive event. At the same time, certain constructions of the event appeared to be manipulated by people who had specific ends in view. Members of the government, in particular, seemed anxious to use the event to advocate a particular vision of the government itself, while at the same time fending off certain meanings people might see in the eclipse. Understanding Javanese responses to the eclipse, therefore, requires that we abandon any simple-minded dichotomy between "traditional" and "modern" reactions to the event, or worse, "cultural" versus "rational" factors underlying them.

It should be noted at the outset that the great anxiety the eclipse aroused was not "traditional." Solar eclipses are too rare to have given rise to conventionalized responses, and Javanese have neither lore nor practices with which to treat such an event. Lunar eclipses are, of course, more frequent, and a legend explains that a lunar eclipse occurs when a monster swallows the moon. When the monster is shot with an arrow by Wisnu, its body falls to earth. Its trunk turns into the hollowed-out log, and its arms and legs turn into the wooden pestles with which women used to hull rice. To this day, children pound these rice-hulling logs during a lunar eclipse to cause the monster pain and make him give up the moon. But this legend does not touch on solar eclipses, and most Javanese are, in any case, too sophisticated to accept such traditional lore as a true or complete explanation of a natural event. So while I believe it necessary to approach Javanese responses to the eclipse with reference to general issues in Javanese culture, neither Javanese nor an outsider could say that they reacted as they did in imitation of their forebears. Nor did they experience fear out of surprise at an unanticipated cosmological event. On the contrary, it was the great amount of forewarning in the media and on the part of the government that caused this fear.

I should explain what I brought to my own interpretation of the event. My earlier research in Java had focused on shadow plays, Java's most prestigious art form. To understand why this unusual, night-long performance held such fascination for Javanese, I found that I had to analyze Javanese ideas about the relations between the performance and its spectators. That meant asking who a spectator is, and so who a person is, in Java; how people establish and maintain their identity and status, and how such concerns govern interaction. External concentrations of power suggest sources of both aid and attack on the Javanese self. A shadow puppeteer does not exert overt political control over people, but this makes his considerable power over their attention and thoughts all the more ambiguous, intriguing, and troubling. On returning to Java in 1983, I was struck by how these issues of authority and submission seemed to pertain once again to 
Javanese reactions to the eclipse, a very different sort of performance to be sure, but one which raised similar questions about power, authority, and the integrity of the self.

Much about the fear people experienced at the time of the eclipse follows from some quite generally held Javanese assumptions, and I will outline these before going on to consider the government's particular motivations. Javanese are much concerned, first of all, with personal vulnerability to external influence. Influence can be of many sorts. In interaction, high status means being exempt from others' control, while low status means being subject to commands. People express their dependence by requesting the beneficent influence of an elder or superior to be exercised on their behalf. A superior, in contrast, is someone-usually a male-thought to have attained that status through a deliberate resistance to all external or internal pressures. In the course of ascetic exercises, such a person must overcome all desire for food, sleep, sex, or money, and overcome as well all weakness in the face of threats made upon his person. These threats may take the form of ghosts, monsters, tigers, or beautiful and seductive women. In resisting them, he proves himself impervious to the world. The spiritually weak, in contrast, stand in danger of being entered by spirits, causing them delirium and uncontrolled behavior. Another kind of penetration, by wind (masuk angin), accounts for most common illnesses in Java. People guard against this by zipping up jackets and closing windows when riding a bus, or tying handkerchiefs over their mouths when riding a motorcycle.

Mystical penetration can define hostile relations, not only between humans and spirits, but also among humans. Interpersonal enmity only very occasionally takes the form of physical violence in Java. It is believed, instead, to elicit magical practices. A person goes to a specialist in black magic and has him direct invisible attacks upon the person who is targeted. Such attacks are often thought to take the form of sharp instruments that insensibly penetrate the victim's stomach, inducing sickness and death. One evening in Karanganom, Pak Cerma and his wife were eating in the kitchen, behind the house, when a loud noise was heard from inside the house. Nothing could be seen to have fallen, and Pak Cerma interpreted the noise as an enemy's foiled attempt to direct evil magic against him or some member of his family. He mentioned that occasionally, when his father was still alive, as he and his father sat up at night a noise could be heard as of something falling on the roof and then sliding down the tiles. His father would say quietly, "Someone doesn't like us. But never mind." There was no point in looking outside. There would turn out to be nothing there. The noise was the sound of evil magic materializing and falling because of the superior power of its intended victims. But it would then leave no trace.

The enclosed space of the house, as Pak Cerma's recollection implies, affords protection from mystical attack as well as from human intruders. The houses of well-to-do peasants in Java have traditionally consisted of a series of wooden doors to the outside, doors that can be opened during the day or removed to accommodate a great many guests on ritual occasions; and an inner area, separated from the first room by another panel of doors, that is not usually open to guests. At sunset, both sets of doors are secured. Only recently have Javanese begun constructing houses with windows and air vents. These were not included in traditional Javanese construction, probably because they suggest a permanent openness to the outside, a distinctly ill-considered condition and one that contradicts the opposition between open and closed space implicit in a Javanese house's design.

That Javanese should have closed all openings to the outside before the eclipse and then huddled together in their houses for the duration follows from their concern to 
protect themselves from external influence and attack. In fact, the talk of "sharp rays" and efforts to prevent their penetration suggested their assimilation to the category of sharp objects that can penetrate one's belly.

If sitting inside the house is the first line of defense against attack, moving about is always a somewhat risky business. Movement past certain spots is especially likely to occasion disturbances. Dark thickets of bamboo, springs, great trees, and crossroads, all harbor spirits that can attach themselves to people and cause them harm. This is particularly true at certain times, most notably noon and dusk, when spirits are thought to be most active. I believe the fear of going outside during the time prior to and during the eclipse fits into this general Javanese suspicion of movement abroad, especially at times of cosmological transition.

The special dangers implicit in liminal time periods such as noon and dusk, and in crossroads, fit into a Javanese belief in the equivocal power of conjunctions, and this belief is another pertinent factor in analyzing Javanese responses to the eclipse, seen as a cosmic conjunction. All conjunctions, whether temporal or spatial, suggest the unleashing of mystical power, and this detonation may be auspicious or harmful. Interpreting many kinds of signs consists of fitting them into the context of temporal conjunctions and determining whether they signal good or ill. One does this by consulting books (primbon) that provide accounts of signs' meanings. For example, Central Java is often shaken by earth tremors. These are taken to be signs of impending events, and the time, date, and month of an earth tremor are all noted by Javanese and checked in primbon. These provide predictions of positive or negative influences or events to follow. Rather than having any single, permanent significance, an earth tremor bodes well or ill according to when it occurs, that is, at what point it fits into several intercalated cycles.

If the power of conjunctions is ambiguous according to when they occur, it is also thought that the condition of the person who wants to make use of that power can determine how it affects him or her. The lower people's status, the more careful they must be to avoid potent conjunctions. The first ten days to two weeks of the Javanese year, at the beginning of the lunar month of Sura, are thought to be too powerful for commoners in Java to hold ritual celebrations. It is at this time that the Sultan of Yogyakarta is believed to meet with Nyai Rara Kidul, the beautiful and dangerous queen of the southern sea, and only spirits and aristocrats are entitled-and mystically powerful enoughto hold rituals during this period. I assume it is a similar belief in the too-great power of the day that prevents Javanese from celebrating Indonesian independence on Independence Day, which is August 17. None of the many entertainments and athletic events held to celebrate the event occurs on the seventeenth itself, but rather sometime during the ten days or so after that date.

The solar eclipse was construed by Javanese as a particularly potent and ambiguous conjunction. Lunar eclipses are regularly included in Javanese primbon, and some primbon group solar as well as lunar eclipses under a single heading. The two primbon I consulted indicated that an eclipse in the month of Ruwah, the Javanese month in which the eclipse occurred, was auspicious, and many Javanese seemed to have heard similarly encouraging glosses. Such interpretations were not sufficient to assuage all worry, however. Perhaps more telling was the comment made about the eclipse by an old puppeteer, a man who is also often consulted as a ritual expert. He explained that, before it took place, he had reminded guests of an old people's remark that, when a rooster has been chasing a hen and finally catches her, one should look away, lest one suffer conjunctivitis. Similarly, he said, one should look away during the eclipse. My 
delicate questioning as to whether this suggested the intercourse of sun and moon received delicately noncommittal answers. I would certainly not claim that any great proportion of Javanese saw in the eclipse the sexual union of sun and moon. More important, however, than what specific kind of conjunction the eclipse was thought to be was the impression that such a conjunction was too powerful for humans to observe.

Neither fear of mystical penetration nor belief in the need to avoid too-powerful conjunctions, however, would alone have sufficed to induce the avoidance reaction the eclipse aroused among Javanese. These factors became prominent only because of the remarkable publicity the Indonesian government gave to the event. This points to a third factor which conditioned the Javanese response, namely, respect for the government's authority.

Any understanding of the nature of government is shaped concurrently by traditions of long standing and by more specific or recent trends and events, as Braudel suggests in distinguishing la longue durée from la conjoncture and l'événement. ${ }^{3}$ In Java, what could be termed short-, middle-, and long-term political memory all served to induce compliance with official directives at the time of the eclipse. In the colonial period, both Javanese and Dutch authorities were ready to use stern measures to punish any infraction of their control. More recently, the terrible violence that wracked Indonesia in the nineteen sixties is perceived by many people in Central Java as the government's punishment of the Communist Party's disloyalty. Most recently of all, during the months prior to the eclipse, in response to what was seen as an alarming increase in brigandage in Java over the previous few years, the military police had embarked on a campaign to kill recidivist criminals. Public opinion in Java was nearly universally approving of these "mysterious shootings" (penembakan misterius), and I do not mean to suggest that the population lives in terror of the military now, as it once did. But the military's actions could only reinforce popular impressions of the need to pay government instructions careful heed.

Javanese said that they felt afraid (wedi) at the time of the eclipse, but the term actually covers both fear and respect, and it is worth noting that respect for experts' warnings about the dangers of watching the eclipse was just as important as fear of official prohibitions, in persuading Javanese not to watch the eclipse. It was in large part the force of these warnings, and their resonance with the Javanese beliefs discussed above, that made Javanese obey official directives to stay inside the house with neither reluctance nor regret, but rather with fearful conviction.

\section{Official Responses}

Mention of government authority raises the second question I noted at the outset: why the government took such elaborate measures to prevent people from observing the eclipse. Certainly, government officials were genuinely concerned about the effects of the eclipse on people's sight. And the central government did not quite forbid people to watch the eclipse. Experts on television stated that it was safe to observe the eclipse provided one did so through two layers of photographic negatives. (This message was probably thought too complicated to convey to uneducated people: it did not receive much

\footnotetext{
${ }^{3}$ Fernand Braudel, The Mediterranean and the Mediterranean World in the Age of Phillip II, trans. Sian Reynolds (New York: Harper and Row, 1975).
} 
stress.) It was village officials who were largely responsible for imposing a complete curfew on villagers on the day of the eclipse. Still, markets were closed, policemen stopped all traffic in Yogya, and the military occupied gas stations. Clearly the government's concern included, but also went beyond, a paternalistic regard for the welfare of the citizenry. I believe Indonesian officials, of whom a great many are Javanese, acted both on a belief in the significance of powerful conjunctions, and on a suspicion of how such an event might be construed.

The government's most immediate worry must have been that, if any quarter intended to arouse civic disorder, the solar eclipse would have provided a highly appropriate time to do so. This helps explain why the government wanted to discourage all movement on the roads. In fact, the government was very successful in its efforts to control the actions of millions of people in Java: it was a stunning demonstration of the government's ability to use the media and bureaucracy to control the population. I am inclined to think the government took the event as a kind of exercise, an opportunity to test out its effective control. If so, many officials must have been gratified by the results, since for much of the day of the eclipse Central Java came to a virtual standstill.

Keeping people inside the house, however, was probably not the government's only aim. I have mentioned that great natural events such as earth tremors are taken by Javanese as signs susceptible of interpretation. Interpretation is of interest primarily in as far as it enables a person to foretell events, and the greater the magnitude of an event, the greater the presumed import of what it signals. On the smallest scale, a dream can indicate the future good or ill fortune of individuals and/or their relatives; more grandly great meteorological events, corresponding to shifts in political eras, are important tropes in shadow plays and historical chronicles; and people now see the eruption inf 1963 of Gunung Agung, a volcano on Bali, as the cosmological foreshadowing of the vast civic upheaval of 1965-1966. Of course, the significance of all such signs is not apparent to most people until after the fact, once they have been fulfilled. The potency of the eclipse lay in the potentiality of its significance, in its status as a sign of great, but as yet indeterminate, meaning.

Open-ended political speculation is not a mode of discourse freely engaged in among Javanese, at least not now. Nevertheless, a solar eclipse could only evoke some degree of musing, particularly since the rapid changes now occurring in Javanese life, including vast improvements in communications and transportation, a great influx of imported goods on sale in town, and enormous new pressures to assure one's children advanced education, arouse ambivalent reactions among a great many people in Java. Only a very few people I spoke with alluded, and then only vaguely, to possible implications of the eclipse as a sign of imminent political change. Yet I believe members of the government were aware of, and anxious to forestall, just such inclinations to "make connections" (ngothak-athik) on the basis of a presumed resonance across cosmological and political spheres.

Governments in Indonesia have attempted for a very long time to rule out any impression that there might exist sources of authority apart from their own. This stems in part from traditional Javanese understandings of power as a concentration of energy at the kingdom's center. ${ }^{4}$ But Heather Sutherland has shown how difficult it was for the Dutch colonial administration, as well, to countenance any model of political authority,

${ }^{4}$ See Benedict Anderson, "The Idea of Power in Java," in Culture and Politics in Indonesia, ed. Claire Holt, et al. (Ithaca, NY: Cornell University Press, 1972), pp. 1-62. 
other than that of a central source of power which imposed demands upon lower levels in a monolithic hierarchy. ${ }^{5}$ The current government has maintained that view. Its efforts, for example, to coopt both religious orthodoxy and the shadow-play tradition illustrate this general and long-standing suspicion of any kind of alternative authority.

As in any modern nation, however, the contemporary Indonesian bureaucracy differs from its colonial antecedents in its far greater control over all aspects of life. By shaping people's perceptions of the eclipse, the government took a hand in adapting people's understanding of such an event, and of the nature of its own, expansive ends. In their combined show of scientific expertise and political control, Indonesian officials took advantage of television, jeeps, and loudspeakers, as well as Javanese beliefs, to disseminate a distinctly modern view of their authority. What was modern above all was the impression of the state's all-embracing concern, and reach.

The problem that the eclipse presented to the government was that it placed the government in a passive position, commented upon in some vague, but still very significant and authoritative way. It constituted a sign that could reflect upon the government, while remaining completely outside or beyond its control. What the enormous amount of government publicity about the event accomplished, in particular the government's many warnings and instructions, was to place the government in a position of authority, if not quite control. If the government was not in charge of the cosmos, it was at least in thick with it. In the end, it was difficult to watch the eclipse on television without obtaining the impression that this cosmic performance was being sponsored by (disponsori oleh) the Indonesian government itself.

Nonetheless, the government could not alter the fundamental meaning of a great cosmic event, which for Javanese suggests imminent change. There is no such thing as a retrospective omen, much less a congratulatory one. The cosmos does not pay tribute to a job well done. On the contrary, cosmological events point only to what will happen in the future. So the Indonesian government could use the eclipse as an occasion to demonstrate its power, but it could not actually deal with the event's meaning, because the future, like the cosmos, lies beyond its grasp. At most, the government could try to counter inferences about change with a display of unquestionable, and stable, authority. Yet there was no way to drive thoughts about what the eclipse might mean completely out of mind.

Comments made by people in Karanganom suggest that for them the government's authority was indeed at issue. Before the eclipse, people mentioned that, for all the government's warnings, there were sure to be some people who would insist on looking at the eclipse. "Javanese are like that," many people state, "Whatever you tell them they can't do, that's what they want to do in the worst way." Afterwards, the stories that spread about people going blind from watching the eclipse usually concerned students who, it was said, wanted to see whether the government's warnings were really justified. People clucked their tongues at this skepticism. They found it surprising that educated people should behave so rashly-since they, above all, should understand what they are told-and yet at the same time only to be expected-since it is clever, educated people (wong pinter) who refuse to accept anything on authority. There was a note of satisfaction in people's tone as they recounted such stories: now these students would have the rest of their lives to reflect upon their foolhardiness.

${ }^{5}$ Heather Sutherland, The Making of a Bureaucratic Elite: The Colonial Transformation of Javanese Priyayi (Singapore: Heineman Educational Books, 1979). 
People were very impressed by the fact that experts had been able to predict the date and time of the eclipse so accurately. The word for "predictions" (ramalan) here evokes the mystical foresight of such powerful figures as the nineteenth century court poet Ranggawarsita, or the legendary king, Jayabaya, who could foretell Javanese history with great precision. (Many elders in Java are thought to this day to enjoy such foreknowledge of events, though they are said to be too discreet to reveal God's intentions before they become manifest.) The experts' prescience enhanced the government's prestige: experts and the government are not distinguished in the popular mind. Yet the issue of authority accepted or rejected pertained here, too. A woman told me, before the eclipse, that people were placing bets on whether or not the eclipse would really occur at the predicted time, but that the government had forbidden all such betting. To indulge in it was to disbelieve the government. And that, she added, is something the government does not permit.

\section{Conclusion}

The assumptions implicit in Javanese understandings of the eclipse were certainly deeply rooted, but this did not make such ideas immune to manipulation, whether by affirming, modulating, and/or attempting to subvert them. A further incident highlights this point. News reached Karanganom that an old man in a village nearby had disobeyed all directives and gone outside during the eclipse. But he had done so while holding up to the sun his kris, a type of Javanese sword often believed to possess great mystical power. As a result, he had escaped all harm. By this move he impressed people with his sword's power-and with his own as well, since only a powerful person can keep possession of a potent object without suffering ill effects. He thereby bolstered his claims to the respected status of a mystically powerful elder: he had used the eclipse to his own purposes, much as the government attempted to do.

The government, however, had in its exclusive access to the mass media another resource at hand in its efforts to constrain the way the event was interpreted: namely, language. In fact, the terms in which the event was talked about succinctly summarize the interplay of Javanese responses to the eclipse and the government's efforts to control those responses.

I have alluded to the fact that people appeared to react quite differently to the eclipse in Java and Sulawesi. Javanese I spoke with nonetheless conceived of the event as a preeminently national one, and this impression was fostered by means of language. I never heard anyone say "eclipse of the sun" in Javanese, only in Indonesian, though the words are available in Javanese, and even though some Javanese speakers, especially women, are not comfortable speaking Indonesian. The phrases that were on everyone's lips, such as "sharp rays" (sinar tajam) and "total solar eclipse" (gerhana mata hari total), were all said in Indonesian, no matter whether speakers were conversing in Indonesian or Javanese. (The second phrase, often rendered GMT, was actually an amalgam of Indonesian and English. Indonesian has borrowed from English extensively, but this was the first use of total I had encountered in Indonesia.) This use of Indonesian reflected the source of the phrases in radio and television, media in which most programming is in Indonesian, and in which these phrases were repeated in Indonesian even when programming was in Javanese. It meant that people in Java, while construing the eclipse in many ways familiar to them, nevertheless experienced it in a language irrevocably associated in their minds with national and bureaucratic interests, with scientific modes of 
knowing, and with modernity. By means of language, the government embraced the eclipse, or attempted to embrace it, within its national project, and to make of it not a reflection upon the government's authority, but yet another of that authority's many expressions. 